\title{
Entrevista: Reflexões de um reformador contemporâneo do Estado brasileiro: entrevista com Luiz Carlos Bresser Pereira, por Leonardo Queiroz Leite
}

(Manuscrito convidado)

Leonardo Queiroz Leite

Universidade Federal de São Carlos

Luiz Carlos Bresser Pereira é professor emérito da Fundação Getulio Vargas de São Paulo. É formado em direito pela Universidade de São Paulo, tem título de mestre em administração de empresas pela Michigan State University (1961), de doutor e livre-docente em economia na USP (1972 e 1984). É doutor honoris causa pela Universidade de Buenos Aires. Foi ministro de Estado da Fazenda (1987), ministro da Administração Federal e Reforma do Estado (Mare), entre 1995 e 1998, e ministro da Ciência e Tecnologia (1999).

Esta entrevista foi concedida em 6 de dezembro de 2013 ao pesquisador Leonardo Queiroz Leite, como importante subsídio para sua dissertação de mestrado do Programa de Pós-Graduação em Ciência Política da Universidade Federal de São Carlos, intitulada Um empreendedor público em ação: Bresser Pereira e a Reforma Gerencial da Administração Pública de 1995 no Brasil, que focaliza o papel empreendedor do ex-ministro na formulação, defesa e difusão das ideias e inovações fundamentais do gerencialismo, introduzindo no setor público brasileiro os princípios da chamada nova gestão pública. A transcrição completa da entrevista foi revista pelo entrevistado antes de sua autorização para publicação.

O trabalho baseia-se em algumas teorias de análise de políticas públicas que atribuem um papel central aos chamados "empreendedores de políticas públicas", ou seja, indivíduos com perfil inovador e dinâmico que são capazes de posicionar estrategicamente certos temas nas agendas políticas dos governos, lançando mão de recursos de persuasão e de estratégias específicas para defender e difundir novas ideias e inovações. No caso da Reforma Gerencial de 1995, Bresser Pereira claramente assume esta função de liderança política e intelectual, ao elaborar e defender as ideias contidas no Plano Diretor para a Reforma do Aparelho de Estado no Brasil, um instrumento inédito e estruturador da Política de Gestão Pública do primeiro governo Fernando Henrique Cardoso (1995-98).

DOI: http://dx.doi.org/10.1590/0034-76122043

Entrevista recebida em 3 abril 2014 e aceita em 21 maio 2014.

Rev. Adm. Pública - Rio de Janeiro 48(4):1051-1070, jul./ago. 2014 
O longo depoimento do professor e ex-ministro traz uma narrativa mais detida sobre a sua atuação à frente da Reforma, com destaque para o papel desempenhado pela equipe de alto nível que compôs os quadros do Mare, capaz de subsidiar suas ações políticas e seus debates polêmicos. Além disso, Bresser narra como se articulou para conquistar o apoio de alguns segmentos políticos e burocráticos estratégicos durante a discussão da reforma administrativa. Destaque-se também o papel de Bresser na presidência do Clad, um fórum de discussões internacional sobre a Reforma do Estado, que serviu como importante plataforma para a difusão de suas ideias e propostas, bem como a influência do ex-ministro nas propostas do BID e as divergências com o Banco Mundial sobre as ideias para a reforma da administração pública naquele contexto internacional da década de 1990.

Bresser explicita como alguns conflitos dentro e fora do governo frearam suas pretensões reformistas e expõe suas principais dificuldades para fazer avançar sua proposta de reforma gerencial, valorizando a necessidade de debates abertos e transparentes para o convencimento dos setores que seriam afetados pela reforma.

Embora tenha enfrentado críticas e resistências - especialmente pelo fato de ter ido conhecer in loco a experiência gerencial inglesa - às quais Bresser analisa e rebate na entrevista, o tema da Reforma Gerencial difundido por ele no Brasil gerou um intenso debate, tanto no plano político quanto no mundo acadêmico, que está presente até hoje, especialmente nas discussões e ações sobre reformas administravas no plano dos estados, atestando a validade e a perenidade das ideias reformadoras fomentadas pelo ex-ministro.

Estudioso de formação acadêmica ampla e multifacetada, que exerceu a dupla função de intelectual público e homem de ação política, Bresser Pereira merece o reconhecimento como distinto membro da intelligentsia brasileira, cujas contribuições para o avanço da Gestão Pública no Brasil são maiúsculas e permanentes, e por isso exigem estudo e reflexão por parte daqueles interessados na melhoria da performance do Estado brasileiro. Para tanto, este relato de um ministro reformador pode servir como fonte de conhecimento e inspiração tanto para acadêmicos quanto para gestores públicos - para novas e necessárias reformas na administração pública brasileira.

Como suas passagens anteriores por cargos políticos e sua trajetória intelectual contribuíram para te preparar para estar à frente de uma reforma de tamanha magnitude?

Eu sou professor da Fundação Getulio Vargas em São Paulo desde 1959 até hoje. Primeiro, comecei a estudar administração de empresas. Para entrar na FGV era necessário fazer o concurso e depois fazer um MBA em administração de empresas nos EUA; não se podia ter outro percurso. Ainda que meu plano fosse ser sociólogo ou economista do desenvolvimento, era esse o jeito que eu encontrei para seguir esse caminho.

Em 1970 a FGV lançou o curso de graduação em administração pública, e eu dei aulas nesse programa; aí eu começava a ter uma relação mais próxima com o campo. No início dos anos 1980, a FGV/EAESP lançou um curso de pós-graduação/mestrado em planejamento urbano e finanças públicas, onde já começaram a aparecer pessoas interessadas em admi- 
nistração pública propriamente dita, e eu tive duas ou três orientandas nesse período. Uma certamente foi a Cláudia Costin e a outra foi a Evelyn Levy. Essas duas, assim como Ângela Santana, cujo mestrado foi em administração de empresas, tornaram-se depois notáveis administradoras públicas e parte de minha equipe no Mare.

Por outro lado, eu sempre me interessei não apenas por economia, mas por teoria social e teoria política, e, portanto, sempre estudei o Estado. Eu já escrevi um livro chamado Estado e subdesenvolvimento industrializado, publicado em 1977. Então, ao estudar o Estado e ao estudar a burocracia - ou a tecnoburocracia, como a chamei —, nisso eu estava outra vez às voltas com administração pública, embora a minha tecnoburocracia não fosse, como muita gente pensou, formada apenas por servidores públicos; é formada pela classe média profissional tanto do setor privado quanto do setor público. Aliás, o fato novo foi quando, a partir do final do século XIX e começo do século XX nos EUA, as empresas privadas se tornam tão grandes e substituem as famílias e as empresas familiares no papel de unidades básicas da produção social. Ocorria então o que denomino "revolução organizacional", e começa a surgir uma nova classe social que é a tecnoburocracia. Eu sempre tive também um grande interesse por essa classe tecnoburocrática e em particular pelos tecnoburocratas públicos.

A minha primeira função política foi no governo Montoro, o primeiro governo estadual democrático que houve em São Paulo, de 1983 a 1986. Nos dois últimos anos, em 1985 e 1986, eu fui o secretário do governo. E eu sabia que a administração pública era uma coisa fundamental para o país. Por outro lado eu conhecia a queixa dos professores de administração pública da FGV que diziam que não havia demanda para os seus formandos. E estava muito claro para mim que não havia demanda ou mercado por uma razão simples, porque o serviço público não tinha carreiras que pagassem bons salários e interessassem aos administradores públicos de bom nível. E nem havia concursos públicos regulares.

No meu entendimento, deveria haver carreiras de administrador público bem remuneradas e os concursos deveriam ser anuais, de forma que um jovem que quer ser administrador público possa programar sua vida para fazer um curso universitário, preparar-se para o concurso e se tornar administrador público. Não havia carreiras desse tipo em Brasília, e não havia em São Paulo. No governo federal só havia carreiras bem reguladas, bem remuneradas, e com concursos anuais na área de diplomacia, na área militar e na área jurídica.

Ainda na Secretaria do governo Montoro, eu propus ao governador e nós apresentamos um projeto de lei para criar uma carreira de administrador público. Na verdade, havia lá uma carreira que nós queríamos mudar completamente, melhorar sua definição e pagar um salário muito mais alto. Mas eu só propus isso nos últimos seis meses do governo Montoro e não deu tempo para aprovar. Houve uma votação já no final do governo, em 1986, na Assembleia Legislativa, em que nós perdemos.

Em 1987 eu me torno ministro da Fazenda, e lá eu constatei objetivamente que havia falta de administradores públicos em Brasília. Nada de dramático, porque Brasília tinha — e tem — um grupo de administradores públicos paralelos, que não havia feito concurso público; eles ajudavam bastante a administração pública de Brasília; eram técnicos e não gente colocada no cargo por motivos políticos. Isso continua existindo ainda, e agora está aos poucos diminuindo, 
porque desde que eu fui ministro os concursos públicos passaram a ser realizados anualmente e com boa remuneração. E isso foi parte importante da Reforma Gerencial de 1995.

Em dezembro de 1987 eu voltei [para São Paulo], vindo do Ministério da Fazenda. Em 1988, o diretor da EAESP/FGV, Marcos Cintra Cavalcanti, criou uma comissão presidida por mim para reorganizar o curso de pós-graduação em administração pública. Era um curso muito esquisito, com apenas duas áreas: finanças públicas e planejamento urbano, que eram ministradas por professores de finanças de empresas e por arquitetos urbanistas. Marcos solicitou um detalhamento maior da proposta e, em 1989, numa segunda comissão, com o auxílio do professor Peter Spink, nós propusemos a estrutura que é mais ou menos a que existe hoje. Nós criamos um core obrigatório de disciplinas para formar um administrador público, e três áreas de concentração (transformações do Estado, governos locais e finanças públicas) e chamamos o programa de "Administração Pública e Governo" para, com a última palavra, indicar a relação da administração pública com a política e o Estado. A área de planejamento urbano, nós propusemos que fosse abandonada. Foi a partir daí que a FGV realmente passou a ter um curso de pós-graduação em administração pública.

Em 1995 eu me vejo ministro novamente. Quando o presidente Fernando Henrique me perguntou qual ministério eu queria, porque eu havia sido tesoureiro dele [na campanha eleitoral], eu disse que queria ou o Ministério das Relações Exteriores, ou o Mare. Um era um ministério muito grande e muito importante e o outro era um ministério muito pequeno, uma mera e pequena Secretaria da Presidência da República. Felizmente Fernando Henrique com certa dúvida - optou pelo Mare, quer dizer, pela Secretaria da Administração Federal, SAF. Só que, quando eu cheguei na Secretaria, o presidente havia mudado o nome da Secretaria para Mare, Ministério da Administração Federal e Reforma do Estado. Os antecedentes [da minha trajetória até a Reforma] são esses. Há bastantes antecedentes.

A partir dos meus estudos do Estado, eu formara a convicção de que o Estado é um instrumento fundamental da sociedade para a realização dos grandes objetivos políticos de liberdade, bem-estar econômico, justiça social, proteção do ambiente, segurança. Sendo assim, o Brasil precisava de um Estado que fosse capaz. Ora, um Estado capaz precisa ter bons administradores, precisa ter uma boa estrutura, uma boa organização, além de ter uma lei, porque para mim o Estado não é apenas a organização; para mim o Estado é o sistema constitucionallegal/a lei e a organização/administração pública que garante essa lei.

Nessa época, quais foram as suas referências intelectuais fundamentais, formadoras dessa visão?

São tantas. Na área da burocracia, Max Weber. Na área do Estado, além de Weber, Marx, Engels e os teóricos marxistas do Estado do século XX, principalmente Gramsci e Poulantzas.

FHC chegou a propor seu nome para o Itamaraty? Há uma versão do Humberto Falcão Martins de que houve uma resistência e depois o senhor teria sido acomodado no Mare.

Não fui acomodado. Ele me perguntou, como eu disse, o que eu queria, e eu disse esses dois ministérios [MRE ou Mare]. Isso foi quase já no final da composição ministerial, quando ele 
já havia escolhido vários ministros. Depois de falar com o Fernando Henrique, numa determinada manhã, eu acordo, abro o jornal, e a manchete da Folha de S.Paulo era "Bresser foi escolhido para ministro do Itamaraty". O presidente não havia me dito nada. Aí eu telefonei para ele, e ele me disse "Não é bem assim, não tem nada definido ainda". E depois ficou claro que ele havia desistido. Então aconteceu alguma coisa lá que levou o Fernando Henrique a desistir de me convidar para o Itamaraty, porque a Folha não deu essa notícia à toa. Mas ficou a outra interpretação - que eu fui acomodado no Mare. Aí o Humberto está enganado. O Itamaraty é mais importante do que o Mare, nisso não há dúvida, mas a área da administração pública foi, desde o início, uma das minhas escolhas. Embora para mim tenha sido uma maravilha que eu tenha ido para o Mare, porque lá eu pude fazer toda essa Reforma, que foi uma coisa muito importante - espero que para o Brasil - e certamente para mim. No Itamaraty eu não conseguiria fazer essas coisas. Depois, nas explicações sobre porque FHC resolveu recuar, houve de que havia algumas pessoas contra, especialmente o Sarney, mas eu não tenho ideia; eu não sei e pouco importa. O que importa é que eu fiquei muito feliz, porque o Mare era uma das minhas preferências e afinal foi ótimo que eu tenha ficado lá. E o presidente mudou o nome para Mare, que foi a sigla que minha equipe inventou - todo ministério tem uma sigla.

Quando o senhor assume o Mare, a reforma administrativa estava fora da agenda, não havia sido discutida na campanha eleitoral e não constava no Programa do novo governo. Exatamente em qual momento surge a ideia da Reforma?

Surgiu imediatamente e foi ganhando corpo nos três meses seguintes. Na hora que o presidente me convidou para o cargo, eu já comecei a pensar nela. Eu havia lido, uns dois anos atrás, o livro de Osborne e Gaebler, Reinventando o governo, e havia achado muito interessante. Não tinha teoria nenhuma, mas tinha uma história das coisas que estavam acontecendo na administração pública norte-americana que me pareciam muito boas, que faziam toda a lógica, segundo minha visão. Havia outra coisa importante que esqueci de dizer. Desde os anos 1980 eu já tinha clara a ideia da organização social. Contar com organizações mais flexíveis, sem administradores públicos concursados estáveis ou quase estáveis, nas áreas em que não havia poder de Estado envolvido, seria muito bom; implicaria um grande ganho de eficiência. Eu havia sido, nos anos 1980, presidente da Sociedade Amigos da Cinemateca, que é um pequeno órgão do governo federal. E eu vi que precisava fazer isso, e que havia a solução das fundações de apoio, que eram uma resolução de pé quebrado, ilegal mas necessária. Então eu já tinha essa ideia da organização social na cabeça. Creio que as fundações públicas de direito privado, Decreto-Lei ํㅜ 200, de 1967, me haviam de alguma forma inspirado a ideia.

Eu fui para o governo [FHC] com as ideias do Reinventando o governo e da organização social (que não tinha ainda esse nome), mas eu só completei as minhas ideias, só consegui montar o meu modelo da Reforma, de qual deve ser a organização do Estado moderno, quando eu decidi viajar para conhecer melhor o sistema americano. Mas, por sorte, soube que o Osborne estava em Brasília e o convidei para almoçar (foi a única vez que o vi na vida). Aí eu 
disse que estava interessado em ir aos EUA e ele me disse que achava melhor que eu fosse à Grã-Bretanha ou à Nova Zelândia.

A sugestão [de ir à Grã-Bretanha] foi do Osborne?

Sim, porque inicialmente eu só tinha notícias dos EUA, e quando ele me deu a alternativa da Grã-Bretanha ou da Nova Zelândia eu escolhi imediatamente a Grã-Bretanha. Então fui à GrãBretanha e passei lá três ou quatro dias visitando várias coisas, e quando saí de lá fui a Santiago de Compostela, onde havia uma reunião de administradores públicos, bem ortodoxa. E lá eu falava no último dia, e então, na manhã desse dia, eu sentei com a Ângela Santana e desenhei um quadro [das bolinhas], e apresentei. Foi a primeira vez que eu apresentei aquele modelo que seria o resumo teórico da Reforma.

Quando eu cheguei de volta ao Brasil, eu comecei a fazer o Plano Diretor. Eu já estava envolvido na Reforma Constitucional, mas o Plano Diretor só ficou claro para mim a partir desse momento. Aí eu chamei o Caio Marini e a Sheila Ribeiro para me ajudarem a escrever o Plano Diretor. E eu mesmo escrevi, na verdade toda a estrutura é minha. Eu tenho um paper que escrevi ao mesmo tempo, que coincide muito com o Plano, que é o primeiro paper que tem o modelo, "Da administração burocrática à gerencial", que foi publicado no ano seguinte, mas foi escrito no primeiro semestre de 1995.

Com as novas ideias eu transformei um ministério pequeno, uma secretaria da Presidência, num think tank. O Mare era um think tank. Eu sou um acadêmico por vocação e um político por obrigação [para com o país]. Quando eu estive no governo Montoro e no Ministério da Fazenda, eu estava dirigindo organizações muito grandes, e eu não tinha tempo para fazer outra coisa senão dirigi-las, e tomar decisões — definir políticas públicas. Quando eu me vi no Mare, eu tinha um ministério mínimo, um orçamento mínimo, um único órgão que era a Enap (que é uma escola). Resultado: ali eu juntei a atividade política com a atividade acadêmica, e transformei o Mare num centro de pensamento, não apenas porque eu trouxe pessoas que me ajudavam a pensar a Reforma, mas também porque eu chamei outras pessoas para discuti-la, que não eram parte do Mare. Este foi realmente um think tank.

O Sr. se refere ao Mare como um think tank e, devido às limitações do Mare, o ministério se restringia ao "poder das ideias". Em que medida isso foi importante para a Reforma?

Foi muito importante. Quando eu assumi o Ministério e fiz meu pequeno discurso de aceitação e falei que eu queria mexer na estabilidade dos servidores, foi uma tempestade em cima de mim. Ninguém entendeu o que eu queria, e de um modo geral não gostaram; só aos poucos foram entendendo. Quando eu comecei a falar sobre o meu modelo de Reforma (das atividades exclusivas e não exclusivas de Estado etc.), as pessoas ficaram desde o início fascinadas, era uma coisa nova. Eu sempre me lembro do Martus Tavares, um notável servidor público (e foi ministro também), que estava presente como assessor na primeira reunião da Câmara da Reforma do Estado (acho que foram três somente de que o Fernando Henrique participou), 
afirmar: "Afinal temos uma teoria para a reforma da administração pública". Foi uma reação entusiasmada dele, e isso vindo de um economista, que não estava envolvido e nem interessado em fazer a reforma da administração pública, mas era um defensor de um Estado saudável financeiramente, era importante. Ele não pertencia à grei dos gestores públicos, pertencia à grei dos economistas dentro do governo, mas ele percebeu. Isso muita gente também percebeu imediatamente e ajudou muito.

Para mudar as coisas é preciso ter boas ideias. O ideal é quando você tem boas ideias e essas ideias não afetam os interesses de muita gente. Aquelas minhas ideias não representavam custos, a não ser para gente muito incompetente, porque elas só fortaleciam os bons servidores. Então era uma coisa que era boa para todos. Se uma reforma não tiver uma boa ideia por trás, demora muito. E você precisa convencer: a quantidade de vezes que eu atendi a convites para fazer conferências foi enorme. E o que me interessava era fazer conferências para servidores públicos. Eu não estava interessado em fazer conferências para empresários, nem para estudantes, não era meu interesse. Meu interesse era convencer os administradores públicos, porque eu jamais faria uma reforma se eles não tivessem interessados em fazê-la, eles obstruiriam, e ponto final; não foi o que aconteceu porque eles se interessaram.

O senhor fazia treinamentos e conferências para os membros da equipe do Mare?

Eu fiz duas grandes reuniões em finais de semana, em Pirenópolis, seminários só com membros da minha equipe para discutir as ideias. Era uma equipe bastante variada e que também variou um pouco durante o transcurso daqueles quatro anos. Então eu precisava fazê-los participar do processo da reforma e das ideias da reforma diretamente.

A sua equipe estava completamente convencida da viabilidade da Reforma ou o senhor teve que fazer um esforço de convencimento?

Não tive necessidade de fazer grande esforço, eles aceitaram muito rapidamente. A resistência maior foi de um gestor, que eu convidei para ser secretário de recursos humanos (não me lembro neste momento de seu nome). Ele era um gestor, um homem muito competente e de muito boa qualidade, mas com uma visão burocrática muito cerrada, e um pouco depois teve que sair. Mas de um modo geral não tive dificuldade nenhuma com a equipe.

O senhor atuou em vários espaços institucionais e redes específicas, o que caracteriza de maneira típica um empreendedor de políticas públicas. Em qual desses espaços (FGV, Clad, PSDB etc.) as ideias e a Reforma foram mais bem recebidas e onde foi mais importante atuar para difundir essas ideias?

Na verdade eu tinha uma rede que estava à minha frente, que era o serviço público federal. O secretário da Administração Federal só tem algum poder, muito pouco, porque ele faz a folha de pagamento e participa da definição de algumas diretrizes principalmente na área de pessoal. Então a rede que eu tinha interesse estava ali na minha frente que era o governo 
federal, e o que eu precisava era convencer os seus membros. Naturalmente, com o apoio da sociedade, que veio muito facilmente, todos, ou quase todos apoiavam. A dificuldade estava dentro do governo federal, porque havia algumas coisas, especialmente a flexibilização da estabilidade dos servidores públicos stricto sensu, que metia medo em muita gente. A minha rede era essa. As outras redes não tiveram importância, a FGV não teve importância para que a Reforma continuasse, não foram os professores que vinham de lá que me ajudavam. Apenas a Regina Pacheco e a Evelyn Levy, que vieram de lá, foram importantes na Reforma. E nem o Clad; eu que ajudei o Clad, que só contava com uma intelectual de primeira categoria, a Nuria Cunill Grau.

Por outro lado, eu precisava dramaticamente do apoio dos políticos, porque eu tinha uma projeto de emenda constitucional, e precisava do apoio deles; precisava, portanto, me entender com eles. Eu tinha que obter o apoio dos servidores públicos, dos políticos; eu já contava com o apoio dos empresários de um modo geral e da sociedade. Esses dois públicos — a alta burocracia pública e os políticos — eram minha prioridade.

Havia um quarto público, que é um pouco diferente, o público dos professores de direito administrativo, que foi o que me ofereceu mais dificuldade. Eles são os "sacerdotes do Estado". Eles estavam muito acostumados com a ideia de uma administração pública puramente burocrática e tiveram dificuldades para aceitar uma gerencial. Eu também tinha esse público a considerar. E havia também os economistas, que apoiavam a Reforma quando entendiam que aquilo era para cortar despesa. Mas não era principalmente para isso. Eu queria fazer a Reforma para tornar mais eficientes os grandes serviços sociais do Estado, e, portanto, para legitimá-los. Era isso que me interessava. Tornar mais eficientes as atividades de secretarias do governo, como a Secretaria de Política Econômica ou a Secretaria de Proteção do Ambiente, isso não tem importância. O que é importante é que as secretarias, que estão no núcleo estratégico do Estado, tomem boas decisões e isso é outro assunto que não estava diretamente relacionado com a minha Reforma. Em relação aos vários órgãos que estão no núcleo estratégico do Estado, a eficiência não é importante. O importante é a efetividade em garantir que as leis sejam executadas. As pessoas pensam que Max Weber estava fundamentalmente interessado em eficiência, e é um equivoco. Claro que o sistema burocrático weberiano é mais eficiente do que o patrimonialista — é racional-legal —, mas o problema não é ser mais eficiente, é ser efetivo. O problema é ter um serviço profissional, neutro, objetivo, que faz que a lei seja observada. É a efetividade que interessa. Para que interessa a eficiência de um Estado que gasta 7\% do PIB?

Já quando o tamanho do Estado muda para 42\% do PIB, como acontece nos países social-democráticos após a Segunda Guerra Mundial, muda tudo. O que é o Estado moderno hoje? No Brasil não é 42\%, mas nos países ricos a média é 42\% e na Europa é mais que isso. Aliás, esse é o Estado que eu gosto, é o Estado social-democrata e desenvolvimentista. Com a Reforma Gerencial de 1995 eu queria que o Brasil pudesse ser um Estado social-democrata; esse era o meu objetivo principal. E para isso eu precisava que os grandes serviços públicos fossem prestados de maneira não apenas efetiva, mas eficiente, com menor custo para a mesma qualidade, ou com maior qualidade e maior abrangência, pelo mesmo custo. 
Isso apareceu no debate sobre a Reforma quando o princípio da eficiência foi proposto na reforma constitucional?

Na segunda reunião da Câmara da Reforma do Estado, eu fiz a seguinte declaração: aqui em Brasília nós temos três tipos de ministério: os econômicos, que eu não posso ajudar muito, porque têm muito dinheiro e economistas que sabem o que fazer da vida deles. Isso é o Ministério da Fazenda, do Planejamento, da Indústria e da Agricultura. Existe um segundo grupo de ministérios que são os de infraestrutura. Nesses há bastantes engenheiros que sabem administrar e, portanto, também não posso ajudar muito. E finalmente há a área social, que não tem nem recursos e nem capacidade administrativa. E essa é a área que eu afirmei ter absoluta prioridade para tentar ajudar, ou seja, a educação, a saúde e a previdência. Era isso que me interessava. Os grandes serviços públicos prestados nessa área que definem o Estado social, porque são serviços caros, e é para administrar bem esses serviços que as organizações sociais são tão importantes.

Eu nunca fui a favor de um Estado pequeno, eu sou a favor de um Estado grande, grande e eficiente. Por que grande? Porque eu sou um social-democrata e isso quer dizer que eu acredito que o Estado deve prover grandes serviços públicos, em princípio universais. Então, é isso o que eu quero: um excelente sistema de saúde, de educação e de previdência social. E qual é o argumento que os conservadores dão contra isso? É uma pequena frase: "não ponho dinheiro bom em cima de dinheiro ruim". Quer dizer, se esses grandes serviços públicos estão mal administrados, se, como dizem os conservadores, todo o dinheiro que se põe lá vai para o bolso dos burocratas e dos políticos e não atende o povo (o que é mentira, mas enfim, é o que eles dizem), você deslegitima esse tipo de gasto social, e então o Estado acaba se retraindo nessa área. Esse é o objetivo dos conservadores, ou dos neoliberais. E eu estava numa briga muito deliberada contra isso.

Ainda me lembro muito bem de um debate que eu tive no Rio de Janeiro, sobre o SUS, que estava numa bagunça completa naquela época; não tinha dinheiro, não tinha organização, não tinha nada. Um empresário, que era presidente da associação comercial do Rio de Janeiro, gritava: "Eu não quero pôr dinheiro bom em cima de dinheiro ruim", referindo-se ao SUS. Eu já sabia que isso já era falso naquela época, mas eu precisava tornar a tese ainda dos ricos que não queriam pagar impostos ainda mais falsa. E a forma de fazer isso foi trabalhar, reformar o SUS, tornar esse e os demais serviços sociais eficientes ao mesmo tempo que prestassem serviços de boa qualidade.

As críticas da época rotularam a Reforma como "neoliberal", dizendo que ela era contra a burocracia e associaram o governo FHC ao neoliberalismo. Como o senhor lidou com isso? Como esse embate ideológico dificultou o debate?

Isso me deu trabalho, porque eu absolutamente não estava de acordo com isso. A minha Reforma não tinha nada de neoliberal, muito pelo contrário. Mas eu estava fazendo uma distinção muito clara entre o que é ser uma posição de esquerda social-democrata e o que é ser 
defensor do burocratismo. Como eu sou crítico dos capitalistas rentistas, eu sou crítico dos maus burocratas, e especialmente daqueles que não trabalham.

Essa estória de neoliberalismo me deu trabalho, porque o governo FHC, especialmente na área econômica e na área das questões nacionais, foi neoliberal. As privatizações, por exemplo, de atividades públicas monopolistas, que não se deve privatizar. Infelizmente era o pensamento dominante na ocasião, e o governo FHC entrou gostosamente nessa área. Eu só fui criticar isso muitos anos depois, porque eu não podia criticar dentro do governo ou logo depois que saí. Então isso me deu trabalho. Para você não ser neoliberal, você não precisa defender o burocratismo. Um grande problema da social-democracia e dos partidos de centroesquerda social-democratas é que eles são em parte capturados pela burocracia pública corporativista. Isso acontece na Europa com muita clareza. O que interessa para um verdadeiro social-democrata é o povo. E claro, você tem que cuidar muito bem da burocracia pública, como você tem que cuidar muito bem dos empresários. Eu tenho um imenso respeito por burocratas públicos e por empresários. O que eu não gosto nem um pouco são dos capitalistas rentistas, e é claro que eu não gosto também de burocrata sem vergonha. Que são um número relativamente pequeno, e são abrigados por proteções exageradas, como uma estabilidade excessiva.

Na época havia o Regime Jurídico Único...

Eu fiz uma festa com esse Regime Jurídico, ajudado pelo meu maravilhoso secretário de recursos humanos, o Luiz Carlos Capella, um excelente burocrata de Brasília, republicano. Ele fez um estudo da lei do Regime Jurídico Único e me trouxe uma grande quantidade de privilégios absurdos que havia na lei. Então nós fizemos uma medida provisória e acabamos com muitos deles. Dali a alguns meses, ele me trouxe outra lista, e nós também resolvemos com uma segunda medida provisória. E ninguém protestou, foi curiosíssimo. Ninguém disse uma palavra, porque era um escândalo. A Constituição de 1988 foi uma bela Constituição no meu entender. Mas houve gente que também a capturou, inclusive a burocracia pública. Nela se procurou supor que os militares eram contra a burocracia e a boa gestão pública, o que era falso. Eles eram contra a democracia, mas não contra a burocracia. Eles eram burocratas.

Como se deu o apoio dos políticos para a emenda constitucional da Reforma administrativa?

Esse é outro público muito importante, eu precisava do apoio dos políticos. Ainda em janeiro de 1995, no final do mês, o Planalto decidiu fazer reuniões dos ministros envolvidos em Reformas com as bancadas dos partidos de sua coalizão. A minha reforma não estava decidida — quando eu falei com o presidente ele disse que a reforma não estava na agenda —, mas ele não me proibiu. Então se resolveu fazer uma reunião das diversas bancadas dos partidos que apoiavam o governo com os ministros responsáveis. Quem coordenava era o ministro da Justiça, o Nelson Jobim. Estavam nelas representados o Ministério da Fazenda (sempre), o Ministério da Previdência, que estava numa reforma importante, e me puseram lá também. 
E isso foi ótimo, ainda que houvesse dúvidas sobre se o governo apoiaria a reforma. Eu não havia o meu modelo completo ainda (só o teria dois meses depois), mas eu havia já algum modelo.

O que foi importante naquele momento não foi o que eu disse lá, mas foi que eu percebi ali que os governadores e os prefeitos de grandes cidades podiam me ajudar muito, porque eles estavam interessados também na Reforma, porque enfrentavam problemas sérios de administração pública: excesso de pessoal, dificuldade em administrá-lo e excesso de gastos. E aí eu fui atrás deles, sistematicamente, e alguns me ajudaram bastante. O Antônio Brito, por exemplo, que era governador do Rio Grande do Sul, entre outros. E indo atrás dos governadores eu ia atrás também dos secretários de administração pública. E esses secretários passaram a ser parte da minha equipe, de certo modo, porque eu os convidei muitas vezes, os ouvi, discuti com eles; foi muito importante esse apoio e o entendimento com eles; eu também aprendi coisas.

Para fazer uma reforma dessa, você precisava trazer as pessoas para te ajudar e aproveitar as boas ideias delas. Eu tinha a responsabilidade principal das ideias e da coordenação delas, mas os outros precisavam também ser ouvidos. Como também na emenda, eu tratei de falar com todas as bancadas, e em alguns momentos havia dificuldades. Houve um almoço com o Michel Temer, por exemplo, que foi muito importante, porque ele me ajudou com ideias de como fazer um bom compromisso com o Congresso. Havia também o líder do governo na Câmara, na época, o Inocêncio de Oliveira, que era um deputado muito inteligente (sem o nível intelectual do Temer, evidentemente), mas um homem muito esperto que sabia da política. Também uma conversa com ele foi importante para que eu pudesse ajustar a minha emenda às convicções da Câmara, aos políticos, portanto.

Na verdade, o presidente [FHC] só concordou afinal que eu estava autorizado a ir adiante com a Reforma quando ele viu que os governadores estavam apoiando. O Mário Covas, por exemplo, um grande governador, era amigo meu, e depois foi fazer as organizações sociais em São Paulo. Tinha e tenho grande admiração por ele; para mim foi o político mais extraordinário que eu conheci; era um engenheiro e um homem público de alto nível.

O Consad já era um fórum com os secretários estaduais de administração pública nessa época?

Não existia o Consad com esse nome, nessa época. Eu não creio que tenha sido o primeiro, mas eu dei muito prestígio às reuniões com os secretários. Na época do Mare, eu conversei com todos, fazia parte da minha política, isso era muito importante. Quando eu fui escrever a emenda, com a ajuda maravilhosa do Paulo Modesto, eu chamava os secretários, eles iam ao Ministério, eu discutia com eles. Eu procurei fazer uma coisa conjunta com eles. Sobre o Consad, foi a Evelyn Levy, que era minha diretora na Enap, que depois organizou o Consad.

E sobre a discussão das ideias da Reforma no âmbito internacional, qual foi o papel do Clad?

Minha história no Clad é muito simples. Eu estou lá no Ministério, e no primeiro mês eu recebo um telefonema da Venezuela. Quem falava era o diretor executivo do Clad, chamado 
Carlos Blanco. Eu não sabia o que era o Clad, e ele me explicou mais ou menos o que era, e me disse que era a minha vez de ser presidente. Porque era para ser o ex-ministro, que eu havia substituído. Eu aceitei. Aí houve uma primeira reunião do Clad, acho que em maio, em Buenos Aires. Eu cheguei à reunião, e antes de entrar no hotel, eu recebo uma carta do ministro da Administração da Venezuela, dizendo que ele não apoiava a recondução do Carlos Blanco para a direção do Clad. Foi então que eu soube que o Carlos Blanco estava pedindo a mudança no estatuto do Clad para ser reeleito. O governo da Venezuela é que financia fundamentalmente o Clad, cuja sede é em Caracas, e a contribuição da Venezuela é muito maior que a do Brasil, da Argentina e do México, que são os países maiores. Aí eu conheci o Carlos Blanco, e em pouco tempo eu descobri o seguinte: que o Clad era uma instituição quebrada. Havia conseguido algum dinheiro com a Espanha (porque a Venezuela estava em má situação e estava segurando as verbas), mas esse dinheiro havia desaparecido rapidamente em consultorias que o Clad dava sobre como reformar o Estado na América Latina. Um absurdo. Enfim, o fato é que estava quebrado e não tinha importância nenhuma na América Latina. Esse era o organismo que eu estava presidindo. Eu descobri que o Clad tinha três pessoas de nível universitário, em nível gerencial: o Carlos Blanco, que estava terminando o mandato; um executivo financeiro, burocrata competente, o David Edelman; e uma única intelectual, muito boa, a Nuria Cunill Grau, uma mulher de esquerda, muito interessante.

Então era uma organização mínima, num total de 15 ou 16 funcionários. A política que eu adotei no Clad foi mudar o estatuto num ponto: tirar a função do Clad de reformar o Estado latino-americano, porque me parecia desproporcional à sua estrutura. Ao invés, queria transformá-lo num fórum de debates sobre a reforma gerencial na América latina. Eu tive um pequeno trabalho em convencer a Nuria, mas no fim ela ficou convencida. Também propus a criação do Congresso do Clad, porque eles estavam acostumados a fazer conferências caríssimas, com um debatezinho numa sala fechada e acabava. Porque toda a lógica do Clad é a lógica do serviço público tradicional. Eu falei: nada disso, vamos ter um negócio que não vai custar nada, pelo contrário, poderá gerar receita para o Clad, e ao invés de vocês terem cinco ou seis papers, vocês terão mais de 100. Vamos fazer um congresso. Aí eu peguei os diretores do Clad e os levei aos EUA para uma reunião da Lasa (Latin American Studies Association), que tem um imenso congresso que segue a lógica que eu queria para o Clad. E nós fizemos o primeiro congresso - o único congresso do Clad que foi realizado no Brasil - no Hotel Glória, no Rio de Janeiro, em 1996. E aí o Clad renasceu. No último ano do meu mandato eu aprovei uma declaração importante ("Uma Nova Gestão Pública para a América Latina") que os ministros dos países latino-americanos aprovaram. Eu acabei estendendo o meu mandato, e ao invés de ficar dois anos eu fiquei três anos. E depois ainda criaram um conselho técnicocientífico para que eu continuasse ajudando o Clad e eu concordei. O Adam Przeworski, o Oscar Oszlak e outros me ajudaram nesse conselho.

Então o Clad mudou, mas depois houve um retrocesso. Começaram a aprovar cartas de princípios de acordo com a velha lógica burocrática — princípios que não significam nada, 
meros lugares-comuns burocráticos. E um pouco depois a Nuria decidiu voltar para seu país - o Chile.

O senhor acha então que o Clad se transformou num think tank, de alguma forma?

Não. O Clad se transformou num fórum de discussão. A única coisa que é importante no Clad, além da revista Reforma y Democracia que a Nuria continua a editar, é esse Congresso, porque nele se discute de uma forma aberta. É ótimo para as pessoas que trabalham nessa área. Um think tank é um grupo de pessoas que desenvolve ideias. Os think tanks são criativos quase sempre por um período pequeno. A Cepal, por exemplo, foi um think tank importante nos anos 1950 e 1960; depois morreu. Continua lá a instituição, mas não há realmente um sistema de novas ideias. O Iseb foi um think tank importante nos anos 1950, e já estava morrendo quando foi liquidado pelos militares. O Cebrap foi um think tank importante nos anos 1970. O Clad não era um think tank, para isso teria que ter um grupo de pesquisadores que estivessem lá. O Clad é um fórum de discussão.

O que o senhor pensa das críticas que dizem que as ideias da Reforma teriam sido importadas de instituições internacionais?

Alguns insistiam que a Reforma era uma proposta do Banco Mundial, que nos anos 1980 foi encarregado pelo governo norte-americano de ser o instrumento das reformas neoliberais. Sobre esse papel do Banco Mundial, aliás, eu já havia escrito um paper crítico, que foi publicado numa revista internacional, "The World Bank's identity crisis", onde eu mostrei como o Banco Mundial, que era uma organização desenvolvimentista, associada aos economistas estruturalistas do desenvolvimento, entre 1979 e 1981 deu uma virada completa e se tornou um instrumento do neoliberalismo. Eu fiz um paper sobre isso bem cedo, no começo dos anos 1990. Ora, o Banco Mundial foi absolutamente contrário à Reforma; não fez nenhuma ação contra ela, muito menos uma ação a favor. Nos primeiros seis meses do meu Ministério, veio um grupo grande de técnicos do Banco Mundial, sentaram, eu expliquei, eles ouviram e foram embora. That's it. E depois quando eu fui ler o material do Banco Mundial, tudo mostrava que eles estavam preocupados ainda com a clássica saída do Estado patrimonialista para o Estado burocrático. Quando eu estava já dizendo: olha, eu sei que há ainda elementos patrimonialistas no Estado brasileiro e no Estado latino-americano, mas já está mais do que na hora de passarmos do Estado burocrático para o Estado gerencial. Toda a lógica do desenvolvimento é que implica a superposição de fases, e o Banco Mundial estava na filosofia do "sequencialismo", quer dizer, o país teria, primeiro, que completar a reforma burocrática para só depois fazer a reforma gerencial. No último ano que eu estive no Mare (acho que foi em 1998, quando eu ainda era ministro, mas pode ter sido em 1999) o Banco Mundial me convidou para uma grande reunião interna, que eles geralmente realizam na Universidade de Maryland somente para o seu próprio staff. Nessas reuniões-treinamento eles convidam algumas pessoas para debater sobre determinados assuntos. Foi muito interessante, porque 
eu tive que manter um debate forte com seus técnicos, porque eles estavam ali deliberada, forte e firmemente defendendo o sequencialismo. Sequencialismo para o qual eu tinha uma resposta pronta, que eu também dei para eles (naquela época era comum você encontrar defensores do sequencialismo): "está bom, se você insiste eu estou disposto a aceitar a sua ideia e abandonar imediatamente a ideia da Reforma Gerencial; mas com uma condição só: que você defenda que o Brasil deve abandonar de vez a revolução da informática, porque o Brasil ainda não terminou a revolução mecânica". Eu fazia essa brincadeira, porque o sequencialismo é ridículo, é algo escandaloso.

E o BID? No BID a história é muito mais interessante, porque eles ajudaram. Eu conhecia de longa data o Enrique Iglesias, que era o presidente do BID. É um economista, que foi diretor-geral da Cepal; é um uruguaio muito inteligente e competente. Em junho de 1995 o Iglesias veio fazer uma visita oficial ao Brasil, como presidente do BID. E claro, ele foi falar com o presidente, que era velho amigo dele, foi falar com o ministro da Fazenda e com o do Planejamento, e me ignorou, ainda que eu fosse meio amigo dele. O tamanho do meu ministério não justificava sua visita. Mas ele me convidou para um coquetel, e lá eu disse a ele o que eu estava fazendo. Ficou interessado e me chamou para uma sala anexa, que me permitiu explicar melhor a Reforma. Ele disse que era muito interessante o que eu estava fazendo, e que eu podia contar com a sua ajuda. Então eu comecei a preparar o seminário, que foi realizado em maio do ano seguinte, para o qual eu chamei o professor Peter Spink para me ajudar. E nós fizemos, no edifício do Itamaraty, uma grande conferência latino-americana sobre a Reforma Gerencial, que deu origem ao livro Reforma do Estado e administração pública gerencial. Depois disso apresentei um projeto, e eles me deram dinheiro para ajudar a executar a Reforma do Estado. Em 1997, o Enrique me convidou para fazer uma grande conferência no BID, com muitos convidados. A conferência causou muito interesse. Na diretoria do Banco havia um diretor que se ocupava do Estado. Quando terminou a minha conferencia, ele chegou para mim e disse: "Que bom, agora nós temos um modelo de reforma do Estado e o Banco Mundial não tem". Quer dizer, o modelo era o meu, que o BID estava aceitando, e na competição que existe entre as duas agências, o diretor estava assinalando a vantagem que eles passavam a ter.

Como se desenrolaram as missões de cooperação de outros países para a Reforma Gerencial no Brasil?

Foram importantes. Quando eu fui à Grã-Bretanha, já havia a ideia de uma assistência, um sistema de ajuda que os países ricos dão a países em desenvolvimento. Então eu fui lá, conversei com eles, conheci a Kate Jenkins, uma ex-alta servidora do governo inglês que havia gerido o primeiro programa da Reforma Gerencial Britânica, chamado "Next Steps", em 1987. Em julho de 1995, a Kate [na condição de uma consultora privada, pois nessa época já não estava mais contratada pelo governo britânico] veio com um grupo de consultores e fizeram um seminário durante uns dois ou três dias, muito interessante. E depois disso ela passou a vir sistematicamente para dar consultoria para a Reforma. Porque eu declarava sempre, e isso 
está em todo lugar, que eu estava me baseando na experiência que começou na Grã-Bretanha em 1987. (Então eu algumas vezes escutava: "Ah, então a Reforma é neoliberal, porque começou no governo da Margareth Thatcher". E eu respondia: "é verdade que foi no Governo Thatcher, mas também é verdade que naquele mesmo período começou uma reforma igual na Nova Zelândia e na Austrália, que naquele momento tinham governos trabalhistas”). Por outro lado, o mais importante dos assistentes dela [da Kate Jenkins], William Plowden, um importante intelectual do serviço público inglês, contou nesse seminário a história sobre como começou na Grã-Bretanha a Reforma: a Thatcher estava no governo desde 1979, mas a reforma começou só em 1987. Ela estava fazendo uma pressão muito violenta para reduzir custos no setor público, e então reuniu-se um grupo de servidores públicos que decidiu negociar com o governo sua colaboração [eles até então haviam resistido e tinham muito poder]; disseram que iriam participar com a condição de que fosse feita uma reforma que modernizasse o serviço público. Então a Reforma inglesa, segundo o William Plowden, teve origem não na Thatcher, mas no serviço público inglês.

Naquela época surgiu uma literatura sobre o New Public Management (NPM), que eu sempre olhei com um misto de interesse e reserva. Quando, em abril de 1995, eu estive na Grã-Bretanha para conhecer a reforma que estava sendo realizada, eu fui a uma livraria e procurei os livros sobre ela. Encontrei vários, mas o trabalho que mais me interessou foi escrito por um especialista a pedido do sindicato dos ingleses, Peter Fairbrother. Ele analisava o que estava acontecendo usando um tom moderadamente crítico. Foi nesse livro que eu vi a expressão "reforma gerencial". Uma coisa que ninguém nunca tentou fazer foi uma comparação entre as minhas ideias e as ideias do NPM, porque há muitas coisas em comum, mas afinal as ideias são bastante diferentes. Inclusive, porque a realidade brasileira é muito diferente. A Grã-Bretanha não tem concurso público, por exemplo; isso já não faz sentido para eles, que têm um nível de desenvolvimento econômico e social muito mais avançado do que o nosso. Fiz sempre questão de manter e prestigiar o núcleo duro do serviço público que, na Reforma, eu denominei "núcleo estratégico do Estado". Então, minha reforma estava adaptada à realidade do Brasil — isto muito deliberadamente da minha parte. Não estava absolutamente interessado em copiar ideias, mas eu não queria rejeitar boas experiências. Por outro lado, a Reforma tinha um caráter estrutural que não estava claro nos textos do NPM. Eu desenvolvi toda uma teoria que fazia uma análise estrutural dos tipos de propriedade, distinguia a propriedade estatal da pública não estatal, e localizava nesta as organizações sociais. Creio que não havia esse caráter estrutural na NPM. Seus autores estavam mais preocupados em transferir as estratégias de gestão privada para a administração pública. Minha posição em relação à NPM era contraditória. De um lado via nela semelhanças com o modelo ou teoria que eu havia desenvolvido sobre a organização do Estado e tinha interesse em mostrar que a Reforma de 1995 fazia parte de uma mudança mundial - da Reforma Gerencial que nos países ricos acontecia cerca de 100 anos depois, quando o Estado passa a ser social da primeira reforma: a Reforma Burocrática. De outro, eu via nela uma certa orientação neoliberal que eu rejeitava. Uma boa ideia para alguém que quisesse pesquisar esse problema seria comparar minhas ideias com as que estão no livro de Ewan Ferlie, Andrew Pettigrew, Lynn Ashburner e Louise 
Fitzgerald The new public management in action (1996), porque fui eu quem promoveu sua tradução e publicação no Brasil. Eu tive também uma cooperação com os franceses, mas eles não ajudaram em grande coisa, pois naquela época eles estavam bem mais atrasados do que nós na reforma gerencial. Agora estão trabalhando nessa área, mas naquela época, não. Na verdade, o Brasil foi um dos primeiros países a começar uma reforma gerencial, apenas oito anos após a Grã-Bretanha.

Na Grã-Bretanha o senhor chegou a visitar universidades, fez contatos no meio acadêmico também?

Eu conversei com o presidente de uma instituição muito curiosa e muito importante que há na Inglaterra, o Higher Education Funding for England (há um fundo para uma das quatro regiões da Grã-Bretanha), que serve de intermediária entre o governo e as universidades, uma espécie de conselho dotado de poder porque administra a distribuição das verbas para a educação superior aprovadas pelo Parlamento. São eles que fazem a avaliação do ensino superior, e distribuem o dinheiro de acordo com as avaliações. Naquela primeira visita eu não falei com universidades; só falei com os reitores de Oxford e Cambridge quando eu voltei à Grã-Bretanha depois de ter sido nomeado ministro da Ciência e Tecnologia, em 1999.

Qual foi o papel da FGV na composição da sua equipe ministerial do Mare?

A FGV não teve importância enquanto instituição que dialogasse comigo. Nem a FGV e nenhuma outra. Não havia no Brasil instituições que estivessem a par das novas ideias, que tivessem um grupo de pessoas disposto e interessado em dialogar comigo. Mas a FGV foi fundamental, porque eu tive toda a minha formação na FGV, trouxe meus alunos de lá, a Ângela Santana, a Cláudia Costin, a Evelyn Levy, a Regina Pacheco e o Nelson Marconi. Toda essa gente veio da FGV, então a Fundação teve um papel muito importante nesse sentido. Mas não havia na FGV um pensamento nessa direção; o pensamento da Reforma eu desenvolvi enquanto ministro; antes eu tinha apenas algumas ideias.

Sobre o que se produziu academicamente no geral sobre a Reforma do Estado no Brasil, o senhor tem informações?

Uma coisa que me incomodou foi o Flávio da Cunha Rezende (pesquisador) que, logo depois que eu saí do Mare, escreveu um paper e depois um livro no qual chegou à conclusão de que a Reforma havia fracassado. E para ele a razão principal do fracasso da Reforma havia sido o fato de o Mare ter sido extinto. Isso é chamado raciocínio dedutivo. É uma bobagem, porque fui eu que propus a extinção do Mare. A Reforma gerencial foi feita com o acordo do presidente FHC e com uma enorme quantidade de obstáculos apresentada pelos dois ministros do Planalto, o Clóvis Carvalho e o Eduardo Jorge. O Eduardo Jorge é um típico representante da burocracia brasiliense, foi contra expressamente, logo na primeira reunião da Câmara da 
Reforma do Estado com o presidente. Foi então derrotado, mas ele continuou tendo importância. Uma coisa a meu ver absurda foi quando o presidente resolveu indicar uma pessoa para negociar com o Wellington Moreira Franco (que foi o relator da minha emenda constitucional). Ao invés de nomear a mim, ele nomeou o Eduardo Jorge... Isso me deu um trabalho danado; os dois conseguiram estragar um pouco a reforma. Não conseguiram muito, porque a emenda era muito bem estruturada e de certo modo se "autodefendia". Já o Clóvis Carvalho era um engenheiro favorável à Reforma, mas crente que a reforma se fazia simplesmente mudando a cabeça dos servidores públicos, transformando os servidores públicos em gestores públicos modernos através de educação, através do aprendizado, por exemplo, com gurus de administração de empresas. Ora, a Reforma Gerencial de 1995 foi e é uma reforma política, foi a reforma de um órgão fundamental da sociedade que é o Estado, especificamente do aparelho ou organização do Estado. Foi uma reforma envolvendo servidores públicos que têm muito mais uma relação com a política do que com a administração de empresas; é outro mundo. Foi e é uma reforma que só pode avançar com a mudança de leis e políticas públicas. Ele tinha muita dificuldade em entender isso.

Quando terminaram os primeiros quatro anos do governo FHC, a Reforma toda estava feita, no sentido conceitual. No sentindo de reformar o aparelho de Estado brasileiro, implantando as ideias dos planos estratégicos, da administração por objetivos etc., eu estava fazendo esforço, mas não tinha apoio nenhum. Toda a minha reforma valeu-se fundamentalmente da minha capacidade de convencimento, de persuasão. Quer dizer, eu tinha ideias, não tive leis nem decretos, ou os tive muito limitadamente. Eu consegui publicar o Plano Diretor na Imprensa Oficial, mas eu queria que fosse feito como uma portaria ou decreto do presidente, porém isso eu não consegui, porque os ministros no Planalto seguravam. Então tudo dependia da minha capacidade de persuadir. Como eu tinha um conjunto de boas ideias e bons argumentos a favor delas, as ideias haviam prosperado. Mas agora eu precisava implementar, agora eu precisava cobrar das diversas organizações do governo federal, dos seus dirigentes, que as políticas da Reforma fossem adotadas. Eu havia verificado que no Chile havia começado uma reforma do Estado naquela mesma época, mas sem o mesmo grau de sofisticação intelectual. O segredo dessa reforma foi que quem a liderou foi o Ministério do Planejamento, apoiado no orçamento público que esse ministério controla. Quando fui visitar o coordenador da administração pública do governo federal dos EUA, ele me disse o seguinte: "Sabe qual é o meu maior poder? É porque a minha sala é pegada à sala do coordenador do orçamento". Os dois tinham o mesmo nível hierárquico, só que um tinha muito poder e o outro não tinha poder, ou melhor, tinha poder na medida em que este estava associado ao do coordenador do orçamento do Estado americano. Eles conversavam o tempo todo, faziam parte de uma equipe; e se apoiavam no orçamento. Se você ameaça um dirigente de cortar seu orçamento se ele não fizer isto ou aquilo, ele faz. Senão, ele precisa estar convencido, e é mais difícil.

E foi isso que me fez sugerir que o Mare voltasse para o Planejamento, como tinha sido no tempo dos militares. Eu acho que foi um erro da minha parte, porque o ministro do Planejamento ignorou a administração pública, que virou uma secretaria e ficou em segundo pla- 
no, de forma que a reforma pouco andou no governo federal. Outra coisa que me aborreceu foi ouvir de alguns intelectuais que a reforma não fora bem-sucedida. É claro que nem tudo aconteceu e nem está acontecendo de acordo com o que formulei. Eu acho isso uma enorme bobagem porque a meu ver a reforma foi muito bem-sucedida, principalmente nos Estados e nas grandes cidades. Ser bem-sucedida quer dizer que a Reforma está ocorrendo, porque uma reforma dessas precisa de 30 ou 40 anos. Foi o que demorou a reforma burocrática para ocorrer nos países desenvolvidos.

Penso assim porque eu tenho uma formação marxista importante, e empreendi a lógica da história com Marx, o materialismo histórico, que, entendido amplamente, é uma coisa fascinante. Eu aprendi que a Reforma Gerencial é uma coisa que ocorre quase inevitavelmente em um país que se torna social-democrático ou que cria um Estado do bem-estar social. E um Estado se torna um Estado do bem-estar social quando se torna democrático, porque os grandes serviços sociais do Estado se tornam uma demanda dos eleitores. No meu entendimento, depois que um país consegue fazer sua revolução capitalista, mais cedo ou mais tarde ele será democrático. A democracia brasileira é estável, consolidada, porque ela foi feita depois que o Brasil terminou sua revolução capitalista. Quando você tem uma sociedade democrática, o Estado tende necessariamente a se tornar um Estado do bem-estar social. O Estado que mais resistiu a isso foi os EUA, mas está cedendo. A grande reação contra foi o neoliberalismo, mas nesse ponto fracassou. Dizem que acabaram com o Estado do bem-estar social, mas isso é falso. O que fizeram foi flexibilizar as leis trabalhistas, isso os neoliberais conseguiram. E quando você tem um Estado social-democrático, necessariamente você vai ter que fazer uma reforma gerencial, porque esse é um Estado muito grande, que tem grandes serviços que o Estado considera importante oferecer gratuitamente ou quase gratuitamente à população. Em consequência, a reforma gerencial vem mais cedo ou mais tarde. O problema todo é saber, depois que o país se tornou realmente democrático, quanto tempo demora para que ele inicie a Reforma, e com qual qualidade e competência ele a faz. Mas que a Reforma vai acontecer, vai. Logo, a reforma que iniciei está bem-sucedida, está em marcha, porque faz parte da lógica das coisas. Eu me antecipei um pouco, porque o Brasil, que eu saiba, é o único país em desenvolvimento que tem o Estado do bem-estar social. Mas acho que foi bom. O Estado brasileiro não é a maravilha do século, mas é um Estado de bem-estar social, especialmente graças ao SUS e à Previdência Social.

De certa maneira a Reforma Gerencial não continua em implementação nos estados pelas mãos de alguns membros da sua equipe do Mare?

Sem dúvida. Foram o Antônio Augusto Anastasia e a Renata Vilhena que chamaram, para ajudá-los na reforma mineira, o Humberto Falcão, o Caio Marini, o Luiz Arnaldo Pereira da Cunha Jr. e o Flávio Alcoforado. Todos eles trabalharam comigo no Mare. A história do governador Anastasia em relação à Reforma Gerencial de 1995 é muito interessante. Eu não o conhecia antes de chegar ao Mare. O Anastasia é um administrativista, e ele era o secretárioexecutivo do Paulo Paiva, mineiro, que era ministro do Trabalho no primeiro governo FHC. E 
esse ministério era vizinho do Mare. Um dia o Anastasia atravessou o jardim e veio ao Mare, muito entusiasmado com a Reforma, interessadíssimo nela. Gostei muito dele, conversamos muito. E quando foi preciso escrever a primeira minuta da lei de Organizações Sociais, o Paulo Modesto não tinha chegado ainda ao governo, e eu pedi ao Anastasia que deu uma grande contribuição. Então o Anastasia foi meu assessor também, um assessor voluntário. Depois quando ele foi para o governo de Minas Gerais, no primeiro governo do Aécio Neves, como secretário de Planejamento, tendo a Renata Vilhena como seu braço direito, eles, juntos, realizaram o Choque de Gestão que foi uma bela realização.

Muitos estados fizeram reformas. Eu me lembro de Pernambuco, que fez um Plano Diretor da Reforma do Estado, com esse mesmo nome, quase igual ao meu. No Espírito Santo, no Ceará, em São Paulo, em muitos estados, houve grandes avanços. O número de leis de organizações sociais que foram criadas pelo Brasil afora, algumas com grande êxito, como os grandes hospitais de São Paulo, mostra bem isso. Mas cuidado. A Reforma tem um modelo, mas isso não garante boa gestão, que depende de gente competente, boas metas, bons controles e boa cobrança.

Os conflitos intragovernamentais foram os maiores obstáculos que o senhor encontrou durante a Reforma?

Não. Mas foram desagradáveis, e me deram trabalho.

O senhor acha que quebrar o éthos burocrático e convencer a alta burocracia para a adesão à Reforma foi mais difícil?

Não se tratava de quebrar o éthos burocrático, que é fundamental, mas o burocratismo, o entendimento "ortodoxo" do que é a administração pública. Não fui totalmente bem-sucedido nessa tarefa, mas fui essencialmente bem-sucedido. Eu acabei por conquistar o coração e as mentes da alta e competente burocracia de Brasília. Um grande fracasso meu foi a reforma das universidades. O que o governo federal tinha de grande que podia se transformar em organização social? Em primeiro lugar estavam as universidades. E uma das mais importantes delas, que é a Universidade de Brasília, nasceu como uma organização social, junto com o Darcy Ribeiro. Não tinha esse nome, mas toda a lógica era de uma instituição sem fins lucrativos, privada, financiada quase que integralmente, senão integralmente, pelo Estado. Isso, mas um contrato de gestão é uma organização social. Além disso, havia os hospitais federais, que foram minha segunda prioridade, mas a maioria dos hospitais estava dentro das universidades. E eu tentei fazer isso. O ministro da educação, Paulo Renato de Souza, notável educador, era meu amigo, e a Gilda Portugal Gouvêa, que era assessora dele e minha amiga. Então fui tentar convencer o Ministério da Educação a embarcar no plano de transformação das universidades federais em organizações sociais. Não foi fácil, mas afinal eles concordaram. Fundamentalmente, o Paulo Renato e a Gilda concordaram, mas o secretário de Ensino Superior não estava lá muito convencido. Mas nós começamos 
a trabalhar, e a coisa vazou para os reitores. Então o reitor da Universidade Federal de São Carlos fez um artigo violento na Folha de S.Paulo contra a ideia. Os dois principais assessores para o ensino superior recuaram e o ministro também. É por isso que temos um modelo atrasado de universidade pública no Brasil. É principalmente por isso que nossas avaliações internacionais são tão medíocres.

Leonardo Queiroz Leite é bacharel em relações internacionais pela Unesp e especialista em gestão pública pela Fundação Escola de Sociologia e Política de São Paulo. Atualmente é mestrando em ciência política pela Universidade Federal de São Carlos. E-mail: leonardo.queirozleite@gmail.com. 